\title{
Abscission Layer Formation as a Resistance Response of Peruvian Apple Cactus Against Glomerella cingulata
}

\author{
Young Ho Kim and Kwang-Hyung Kim
}

School of Agricultural Biotechnology and Center for Plant Molecular Genetics \& Breeding Research, Seoul National University, 103

Seodun-dong, Kwonseon-gu, Suwon 441-744, Korea.

Accepted for publication 22 April 2002.

\begin{abstract}
Kim, Y. H., and Kim, K.-H. 2002. Abscission layer formation as a resistance response of Peruvian apple cactus against Glomerella cingulata. Phytopathology 92:964-969.

Stem disks from 2-year-old cacti Cereus tetragonus (susceptible) and C. peruvianus (resistant) were inoculated in the center (pith) with Glomerella cingulata isolated from Colletotrichum stem rot in threeangled cacti. The susceptible cactus became extensively colonized, whereas colonization was limited to a small area in the resistant cactus. The resistant cactus formed prominent abscission layers (ALs) in parenchyma internal to the inoculation site. Ethanol extracts of the fungal culture also stimulated AL formation in the resistant cactus. Initial cell division followed at 2 to 4 days after treatment, and layering of multiple cells at 7 days after treatment. After 10 days, the outer layers were some-
\end{abstract}

ABSTRACT times sloughed from the inner layers. No AL formation was induced in susceptible C. tetragonus treated with ethanol extract or in untreated control cacti. Light and electron microscopy revealed that initial cell division occurred by cell wall formation, and that an additional cell wall was layered in pre-existing parenchyma cells without ordinary cell division. Later, separation layers formed in ALs where inner cell walls appeared to be thickened secondarily, and the cell walls and middle lamella within the layer dissolved. These results suggest that AL formation in the resistant cactus is induced by fungal metabolites, and that it serves as a histological barrier against anthracnose pathogens.

Additional keywords: Colletotrichum gloeosporioides, separation layer, ultrastructure.
Glomerella cingulata, the teleomorph of Colletotrichum gloeosporioides, is a physiologically variable group of fungi (5) that destroy a variety of horticultural crops, particularly fleshy organs such as fruit, during the pre- and post-harvest periods. The succulent stem tissues of cacti are attacked by the fungus, causing Colletotrichum stem rot (6). In Korea, the pathogen attacks the three-angled cactus (Hylocereus trigonus), the plain cactus (Gymnocalycium mihanovichii), and the Indian fig cactus (Opuntia ficus-indica) $(13,14)$.

During pathogenesis, many anthracnose pathogens have a twostage hemibiotrophic infection process, comprising an initial biotrophic and later necrotrophic phase $(20,30)$. However, anthracnose pathogens like $G$. cingulata that attack fleshy tissues may become more necrotrophic after penetration, and multiple pectindegrading enzymes lead to tissue rot (15). Unlike biotroph resistance, anthracnose pathogen resistance usually involves complex incompatible processes that are governed by multiple genes (21). Defensive responses to such facultative parasites include the synthesis and accumulation of phytoalexins, which are generally fungitoxic and antibacterial (26), and function as a chemical barrier.

Plants usually form one or more defensive structures to resist infection, including hypersensitive necrotic responses or cytological and histological reactions (1). Although localized cell death (hypersensitive response) prevents the survival and growth of biotrophs, it does not affect necrotrophs, which utilize the dying or dead cells as a food source (28). Most incompatible relations between anthracnose pathogens and host plants occur at the cellular level $(9,30,31)$. In the anthracnose diseases examined so far,

Corresponding author: Y. H. Kim; E-mail address: yhokim@snu.ac.kr

Publication no. P-2002-0708-03R

(C) 2002 The American Phytopathological Society histological defense structures may not form conspicuously, or may have been overlooked.

In a previous study (14), we found that two closely related cactus species, Cereus peruvianus (Peruvian apple cactus) and $C$. tetragonus, exhibited very different patterns of stem rot. C. peruvianus developed small local lesions, while $C$. tetragonus developed extensive rot. In the resistant Peruvian apple cactus, further rot expansion was limited, indicating the presence of mechanisms other than hypersensitive and cellular resistance responses. This study examined the histological changes related to Colletotrichum stem rot resistance in cactus.

\section{MATERIALS AND METHODS}

Pathogen and inoculation. The $G$. cingulata isolate C-1 was obtained from Hylocereus trigonus stem rot (14) and grown in potato dextrose agar (PDA) at $25^{\circ} \mathrm{C}$ for 15 days. Small agar pieces (approximately 1 by $1 \mathrm{~mm}$ ) containing spores and hyphae were inoculated in the pith region at the center of cactus stem disks (approximately $0.8 \mathrm{~cm}$ in thickness) from 2-year-old C. tetragonus (susceptible) and $C$. peruvianus (resistant) cacti (14). The inoculated stem disks were placed on moistened filter paper in petri dishes at $25^{\circ} \mathrm{C}$ in an incubation chamber. The development of rot symptoms was observed daily up to 10 days after inoculation. At 7 days after treatment, when disease symptoms were fully developed, the infected stem tissues (three stem disks for each plant) were cut longitudinally into $50-\mu \mathrm{m}$ sections with a razor blade and observed under a compound light microscope (Axiophot; Zeiss, Germany). The inoculation test showed that an abscission layer (AL) consistently formed in the resistant cactus. The same result was obtained by treatment with fungal culture extract in a preliminary test. Treatment with fungal culture extract induced more synchronized tissue responses, and AL formation could not be examined in the susceptible cactus due to rotting; therefore, we used the extract to examine AL formation. 
Treatment with fungal culture extract. Fully grown fungal cultures on PDA $(\approx 15$ - to 20 -day-old cultures) were macerated in a fivefold volume of $100 \%$ ethanol, centrifuged at 3,000 rpm for 15 min to remove fungal debris and agar, and dehydrated overnight in vacuo in a desiccator. The ethanol extract was dissolved in an equivalent volume of absolute ethanol. Paper disks $(8 \mathrm{~mm}$ in diameter) were soaked with the ethanol solution, dried, and placed on the center of $C$. tetragonus and $C$. peruvianus stem disks. Pure ethanol was used as a control. The treated stem disks were placed on moistened filter paper in petri dishes at $25^{\circ} \mathrm{C}$.

Observation of histological responses. After fungal extract treatment, treated sites were excised and hand-sectioned longitudinally with a razor blade. The sections were observed under a light microscope (Axiophot; Zeiss) after staining with $0.1 \%$ toluidine blue $\mathrm{O}$, which stains lignified, suberized, and tannin-containing tissues blue to green (19). At least three samples were observed per treatment each day.

Electron microscopy. Stem segments from infection sites were cut and fixed in Karnovsky's fixative in cacodylate buffer $(\mathrm{pH}$ 7.0) for $4 \mathrm{~h} \mathrm{(12).} \mathrm{The} \mathrm{segments} \mathrm{were} \mathrm{rinsed} \mathrm{with} \mathrm{the} \mathrm{same} \mathrm{buffer}$ three times for $20 \mathrm{~min}$ each, and postfixed in $1 \%$ osmium tetroxide for $2 \mathrm{~h}$. The samples were washed briefly in distilled water, en bloc stained in $0.5 \%$ uranyl acetate overnight, and then dehydrated in an ethanol series and embedded in Spurr's epoxy resin (27). The embedded samples were sectioned (80 to $90 \mathrm{~nm}$ ) with a diamond knife on an MT-X ultramicrotome (RMC, Inc., Tucson, AZ). Sections were stained with $2 \%$ uranyl acetate and lead citrate for 7 min each and examined under a JEM-1010 electron microscope (JEOL, Ltd., Japan) at $80 \mathrm{kV}$.

\section{RESULTS}

Symptom development. The $G$. cingulata isolate caused severe soft rot symptoms on the stem disks of the susceptible cactus, C. tetragonus; whereas, in resistant $C$. peruvianus, the small black lesion that initially formed remained restricted after further incubation (Fig. 1). In the susceptible cactus, rot symptoms were considerable and extended to deep tissues. In contrast, the deep tissues of the resistant cactus appeared to be intact, forming a clear demarcating layer between the healthy lower and infected upper (brownish) tissues (not photographed). Under a light microscope, the demarcating layer consisted of a band of multiple cells (AL), which later separated from the main stem tissues (data not shown). ALs formed consistently in the resistant cactus after several inoculation tests, and the same results were obtained following treatment with fungal culture extract.

Light microscopy. Cell walls that crossed spherical parenchyma cells and led to cell division frequently formed 2 days after treatment in the resistant cactus. They occurred in a series of cells and formed a layer by 4 days after treatment (Fig. 2A). The newly

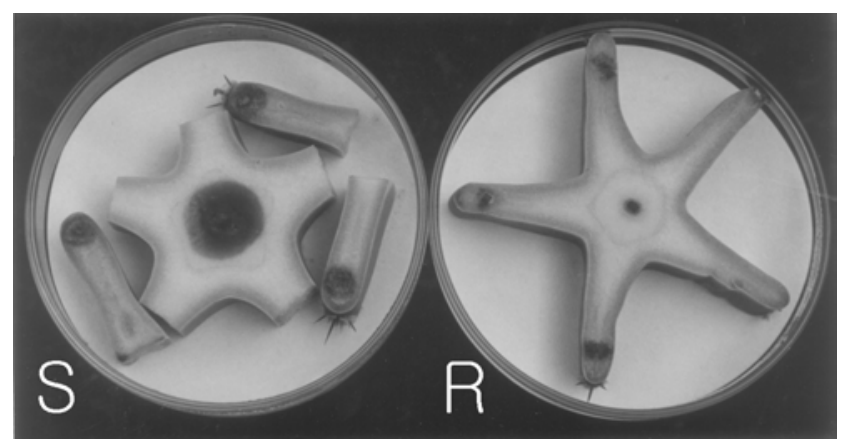

Fig. 1. Rot symptoms developed on stem disks from the susceptible cactus (S) Cereus tetragonus and the resistant cactus (R) C. peruvianus, 7 days after inoculation with Glomerella cingulata. Expansive rot developed on the susceptible cactus disk. A small, localized lesion developed on the resistant stem tissue, under which an extensive abscission layer formed. formed cell walls crossed the cells incompletely, and occasionally diverged from the complete parenchyma cell walls. Although similar cell wall formation was often found 4 days after treatment in the susceptible cactus, it was not consistent between specimens, and a layer of dividing cells was not found (Fig. 2B). At 7 days after treatment, a prominent layer of multiple divided cells that resembled a typical AL formed in the resistant cactus (Fig. 2C), but not in the susceptible cactus (Fig. 2D). At 10 days after treatment, the layer of divided cells became more conspicuous. Separation occurred in the layer (Fig. 2E and F) that had thicker cell walls in the inner layer than in the outer layer. In the susceptible cactus, cell walls also formed, but they were found only in a limited area of tissue (Fig. 2G). Without treatment with fungal culture extract, no layer of divided cells was found in the susceptible or resistant cactus up to 10 days later.

Electron microscopy of $\boldsymbol{C}$. peruvianus. Various cell-division indications were found in the resistant cactus 4 days after treatment, including cytoplasmic strand formation, cell wall divergence, and cell plate formation (Fig. 3). The main feature was cytoplasmic strand formation along the cell wall (accompanying cell wall dissolution) (Fig. 3A), and across the cell (Fig. 3B). The cytoplasmic strands contained mitochondria and numerous dictyosomes and related vesicles, which may be cell plate components (Fig. 3B). Microtubules and a cell plate occasionally formed in the cytoplasmic strands, indicating the initiation of cell wall formation (Fig. 3C). However, the nuclear division typical of normal mitosis was not observed in the dividing cells. Developing cell walls were observed in pre-existing parenchyma cells (Fig. 3D), indicating that the layering of an additional cell wall may also serve as cell division. Additional cell wall layering was noted in several samples by light microscopy (Fig. 3C).
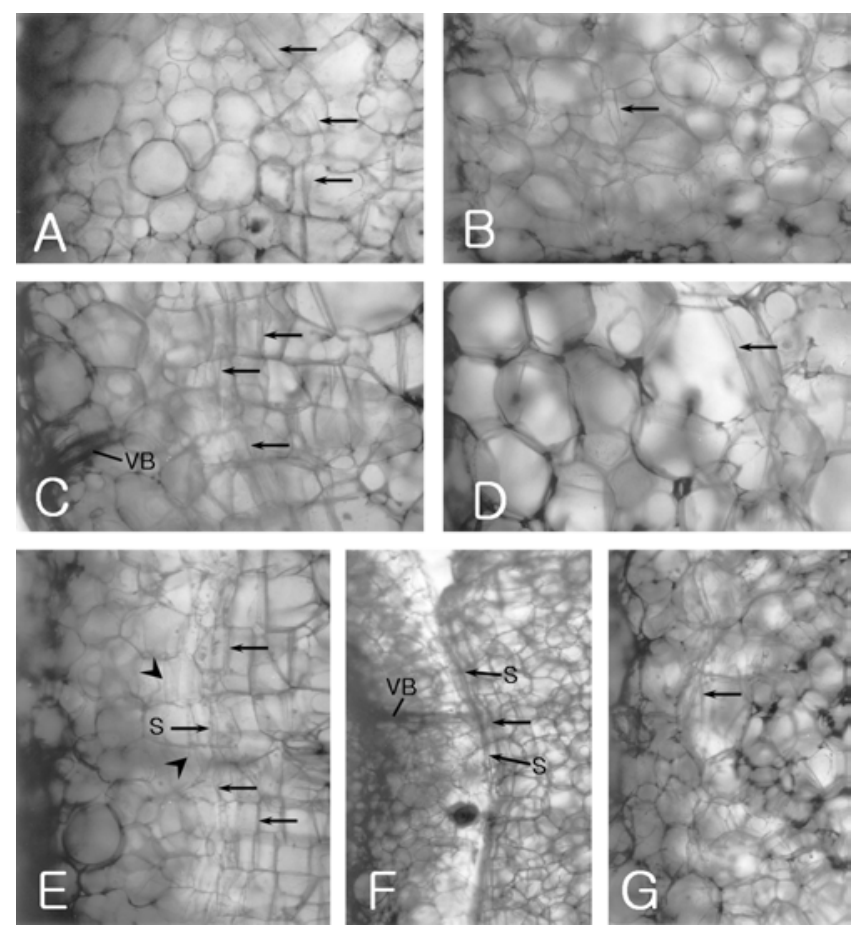

Fig. 2. Light micrographs of stem (pith) parenchyma tissues of A, C, E, and $\mathbf{F}$, the resistant Cereus peruvianus cactus and $\mathbf{B}, \mathbf{D}$, and $\mathbf{G}$, the susceptible $C$. tetragonus cactus treated with ethanol extract of Glomerella cingulata culture. The right sides are surface regions treated with culture extract. Cell division, indicated by cell wall formation (arrow), was conspicuous in $C$. peruvianus from $\mathbf{A}, 4$ days after treatment and prominent at $\mathbf{C}, 7$ and $\mathbf{E}$, 10 days after treatment. Cell separation, indicated by separated cell walls (S) and $\mathbf{F}$, outer tissue abscission, were noted. E, Arrowhead: thin cell wall outside separation region. In C. tetragonus, occasional cell wall formation (arrow) was observed $\mathbf{B}, 4, \mathbf{D}, 7$, and $\mathbf{G}, 10$ days after treatment. VB: vascular bundle. Magnifications: $\times 60$ (A to $\mathbf{E})$, and $\times 25$ (F and G). 
Prominent cell division with parallel cell walls was evident, forming a layer of relatively small rectangular cells, and the initiation of separation was indicated at the distal region (near the treated surface) by contiguous cell wall separation (Fig. 4A). Electron microscopy also revealed layered cells under the distal region with thick, separating cell walls (Fig. 4B). Cell wall separation through the middle lamella (demarcating layer) was noted (Fig. 4C). Cell walls outside the separation region were relatively thin as observed in light microscopy (Fig. 2E). Complete separation included degradation of the middle lamella and cell wall (Fig. 4D). The inner demarcating cell wall had a secondary cell wall, probably composed of suberin.

The separation of affected tissue was more evident at 10 than 7 days after treatment. Generally, the separation region consisted of cells with thick, separating cell walls, thick inner cell walls, and thin outer cell walls (Fig. 5). The complex incorporation of cells in the separation region was revealed by light microscopy (Fig. 5B). The separating walls were completely detached from each other in one area (Fig. 5A); whereas, in another area, the walls were still joined or minimally separated (Fig. 5C). However, the outer walls of both areas were thin (Fig. 5C and D). No definite secondary cell wall formed on the outer wall of the separation region (Fig. 5E), but a thick secondary wall formed on the inner walls (Fig. 5F and G).

\section{DISCUSSION}

Abscission, the normal process used to shed leaves, flowers, and fruit, occurs in a tissue region called the abscission zone. This zone is composed of an abscission or separation layer where detachment occurs, and a protective layer (8). AL formation has long been considered a structural defense against plant pathogens. An early study reported the shot-hole response of Prunus amygdalus, in which leaves discard a disk of infected tissue from the leaf blade by forming separating cells in response to fungal infection (24). Since then, however, little attention has been paid to abscission as a significant structural defense mechanism.

In the present study, the histological responses of $C$. peruvianus to $G$. cingulata infection and cultural extract clearly demonstrated the involvement of AL formation in plant resistance. Fungal metabolites appeared to be responsible for AL formation. The typical abscission process, consisting of initial division of parenchyma cells and enzymatic degradation of the middle lamella and cell walls of the separation layer, was observed by both light and electron microscopy in the resistant cactus. In contrast, the susceptible cactus, which developed extensive stem rot symptoms following infection, did not form an AL after treatment with fungal culture extract.

Light microscopy of the $C$. peruvianus stem AL revealed that the arrangement of divided cells was very similar to the leaf abscission zone of walnut (8). In our study, cell division in the developing AL was achieved by new cell wall formation without obvious nuclear division. The presence of new cell walls in parenchyma cells (Fig. 3C) clearly demonstrated that the resistant cactus AL formed by layering an additional cell wall in pre-existing parenchyma cells. This finding has not previously been reported. Also, ALs were structurally similar to wound periderms, especially during the initial stages (division of parenchymatous cells). Wound periderms are histological defense structures that form in response to wounding and invasion by parasites $(3,18)$, and can be induced by the wound itself $(4,18,22)$. However, the ALs in our study were not induced by wounding alone (i.e., the cut surface of the cactus stem), because they did not form without fungal culture treatment or fungal inoculation. Therefore, AL for-

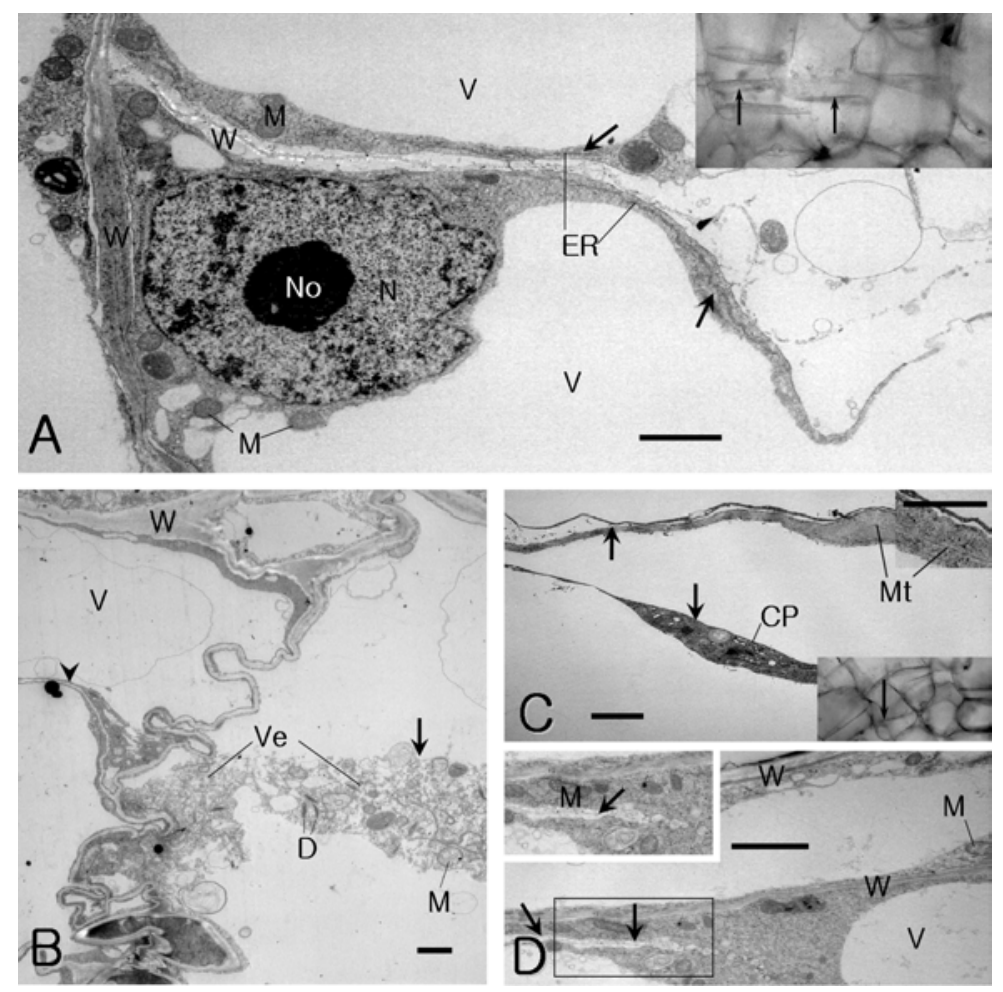

Fig. 3. Electron micrographs of stem parenchyma tissues of Cereus peruvianus 4 days after treatment with Glomerella cingulata culture ethanol extract, showing cell wall formation, leading to cell division. A, Formation of cytoplasmic strands (arrow) accompanied by cell wall dissolution. Inset: Light micrograph (LM) of cell wall formation (arrow) in the same region (×60). B, Formation of cytoplasmic strand (arrow) with increased dictyosomes (D) and related vesicles (Ve), which may be related to cell plate formation. The parenchyma cells have newly formed cell walls (arrowhead). C, Diverging cytoplasmic strands (arrow) that are in the process of cell plate formation as indicated by cell plate (CP) and microtubule (Mt). Inset: LM of the same region, showing diverging cell walls (layering of an additional cell wall, arrow) in pre-existing parenchyma cells. D, Newly developed cell wall (arrow) (layering of an additional cell wall) in the pre-existing parenchyma cell. Inset: Higher $(\times 2)$ magnification of the rectangle region of $\mathbf{D}$. ER: endoplasmic reticulum, M: mitochondria, N: nucleus, No: nucleolus, V: vacuole, W: cell wall. Bars indicate $2 \mu \mathrm{m}$. 

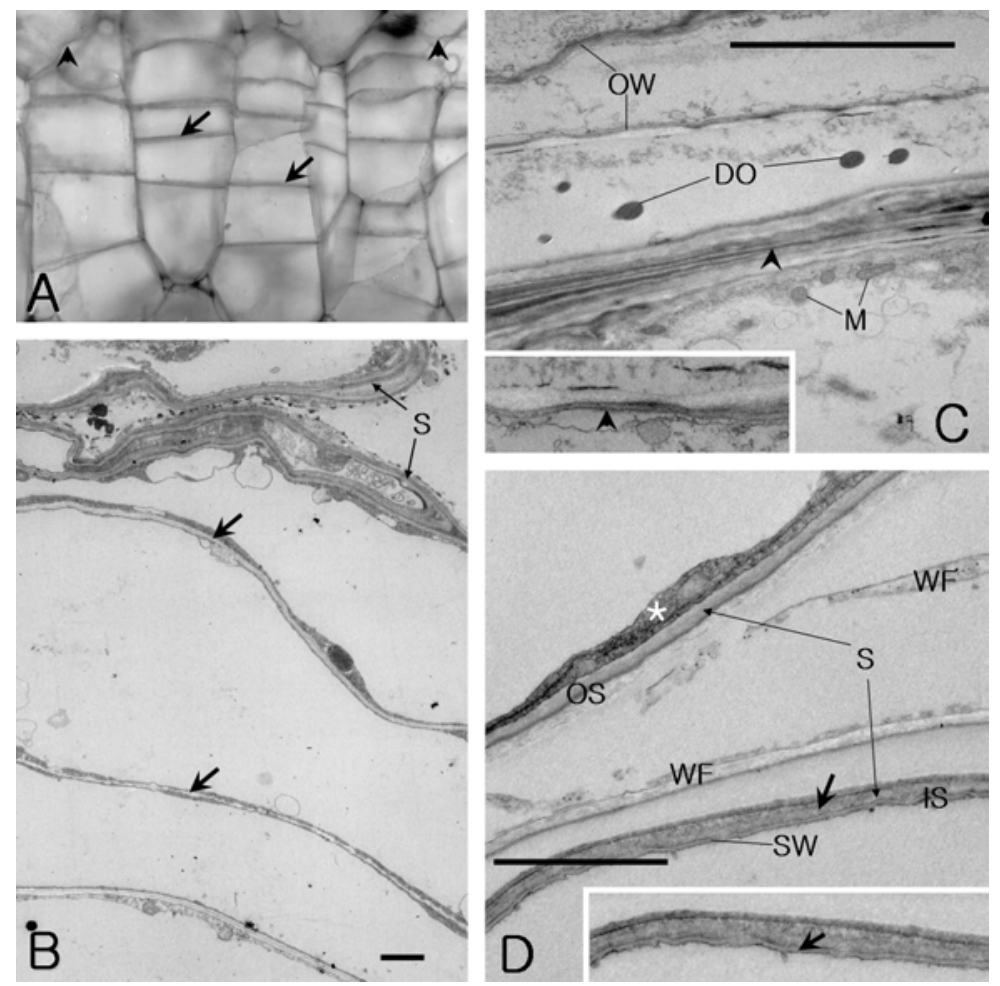

Fig. 4. A, Light micrograph $(\times 120)$ and $\mathbf{B}$ to D, electron micrographs of stem parenchyma tissues of Cereus peruvianus 7 days after treatment with Glomerella cingulata culture ethanol extract, showing cell division (indicated by rectangle cells with cross cell walls, arrow) and separation of contiguous cell walls (arrowhead). B, Inner cell walls (arrow) and cell separation (S). C, Outer thin cell walls (OW) and separation of contiguous cell walls (arrowhead). Inset: Separation of contiguous cell walls (arrowhead) in another region (same magnification). D, Cell separation region (S) containing wall fragments (WF). The inner separation wall has a secondary cell wall (SW), probably composed of suberin, and the cytoplasm of the outer separation cell is necrotic (asterisk). Inset: Higher magnification of the inner separation wall with secondary cell wall (arrow). Bars indicate $2 \mu \mathrm{m}$.

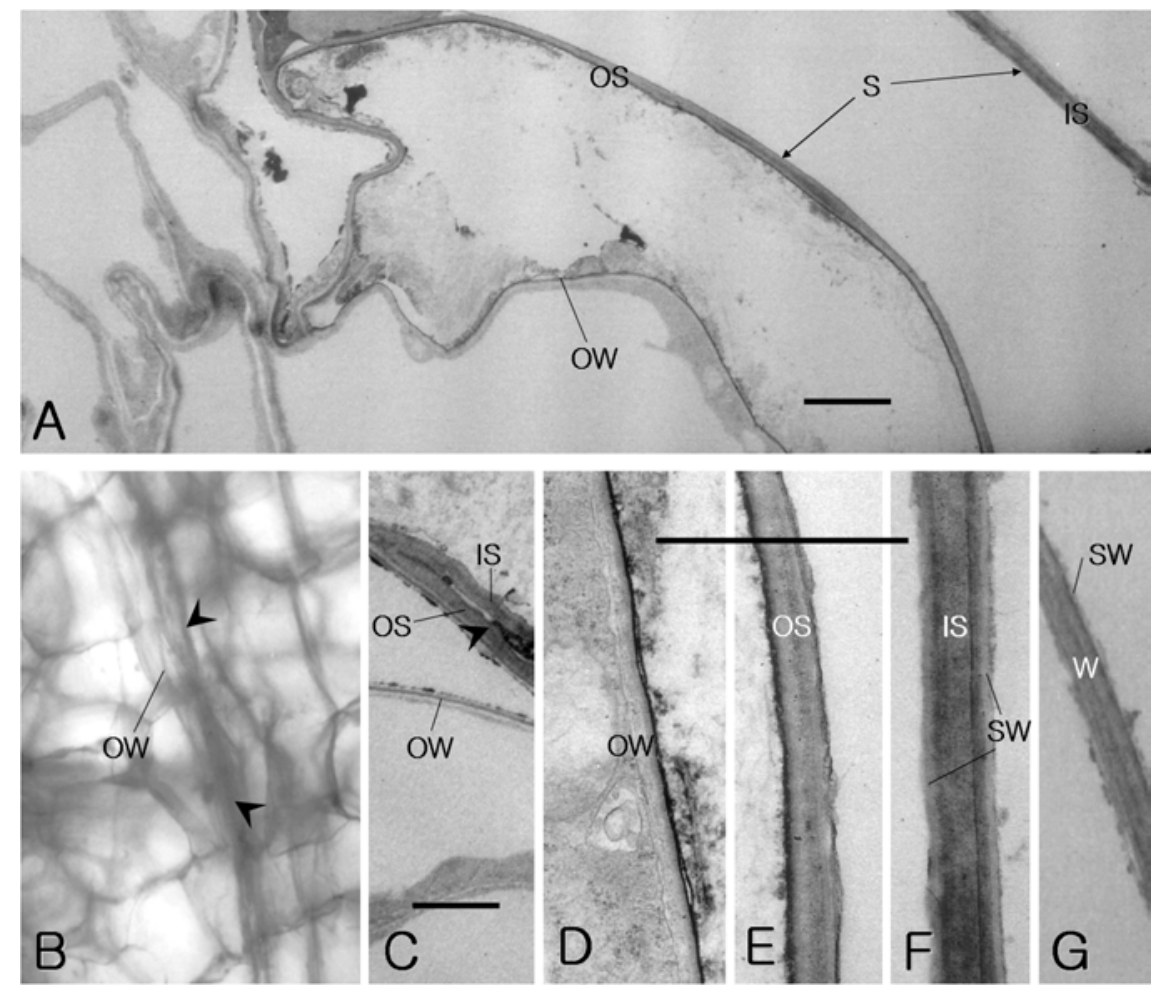

Fig. 5. A and $\mathbf{C}$ to $\mathbf{G}$, Electron micrographs of the $\mathbf{B}$, separation region (light microscopy, $\times 120$ ) in stem parenchyma tissues of Cereus peruvianus 10 days after treatment with Glomerella cingulata culture ethanol extract. A, Separation of contiguous cell walls (S) consisting of inner (IS) and outer separation walls (OS), and outer cell wall $(\mathrm{OW})$. B, Separation of contiguous cell walls (arrowhead) and outer thin cell walls (OW). C, Another region showing initiation of separation (arrowhead) between the inner (IS) and outer separation walls (OS) continuous to those of A. OW: outer thin cell wall. D to F, Higher magnifications of cell walls in $\mathbf{A}$. The first inner separation wall (IS) in $\mathbf{F}$ has a prominent secondary wall (SW). G, The second inner cell wall (W) with secondary cell wall (SW). Bars indicate $2 \mu \mathrm{m}$. 
mation may be specifically induced by fungal metabolites following pathogen infection, particularly in resistant plants.

Like defoliation, the outer tissues eventually detached from the main stem 10 days after treatment with the fungal culture ethanol extract. Although the protective layer typical of leaf abscission was not discernable, the inner cells of the abscission developed a secondary cell wall, a structural characteristic of main stem tissue protection. The walls in the abscission zone may not contain lignin, because toluidine blue $\mathrm{O}$ staining was negative (data not shown). It is generally known that the leaf abscission zone is composed of small, undifferentiated parenchyma cells that secrete a layer of suberin in the walls, but contain no lignin. In addition, under light and electron microscopes, AL morphology resembles the generation of wound periderm on peach bark, where cells have suberized secondary walls (4). The secondary wall lining formed on inner walls of the abscission region in the present study is structurally identical to suberin lining on the inner wall of boundary zone cells on peach bark. Therefore, the secondary walls of inner cells in the abscission zone of the resistant cactus may be composed of suberin. As in wound periderm, the suberized secondary cell walls may prevent internal layer desiccation and inward movement of pathogen toxins or enzymes, and may also serve as physical barriers to fungal colonization. Unlike wound periderm, where the outer cell layer is lignified, the AL may not require lignification because the outer layer is sloughed from the inner tissue.

Abscission zone weakening and organ separation typically occur in most abscission systems (25). During tomato flower pedicel abscission, a 4- to 10-cell-wide separation layer forms, involving the breakdown of the middle lamella and partial degradation of the primary cell wall $(23,29)$. Abscission zone weakening is commonly related to localized synthesis of endoglucanases $(7,16)$ and polygalacturonases $(10,11,23)$. We also found tissue separation by the breakdown of the middle lamella and cell wall, which may result from the same enzymatic activity as that induced in the plant tissues mentioned above.

Although small necrotic local lesions were induced by infection in the resistant cactus, C. peruvianus (Fig. 1), pathogen growth was almost completely inhibited on the cactus stem tissue. After the initial infection stage, G. cingulata is a necrotrophic or semibiotrophic agent, and the AL may not be entirely responsible for the restriction of fungal growth. Some other incompatible plant reactions that occur prior to AL formation, along with constitutive and induced biochemical activity (accumulation of secondary metabolites toxic to fungi) may be related to the resistance. Host barriers can develop at different stages of pathogenesis; in Colletotrichum spp., barriers develop at penetration, appressorium development, and colonization (21). Incompatible cytological responses also are observed during penetration and colonization in other anthracnose diseases $(9,31)$. Appressorium abortion is an incompatibility factor between Colletotrichum spp. and their hosts (17). In an incompatible interaction between Colletotrichum lindemuthianum and Phaseolus vulgaris, phenylalanine ammonia-lyase and chalcone synthase mRNAs accumulate early at the infection site, prior to the onset of phytoalexin accumulation and hypersensitive resistance (2). Although the infection process may vary depending on the anthracnose fungus-host relationship, involvement of the aspects described above cannot be ruled out in $C$. peruvianus's resistance to $G$. cingulata. Nevertheless, AL formation may be a definite resistance mechanism in Colletotrichum stem rot of cactus, based on its relevance (formation following fungal infection and treatment with culture extract), specificity, and structural characteristics. This system also can be used as a tool for genetic studies of structural defense mechanisms, and as an abscission model.

\section{ACKNOWLEDGMENTS}

This work was supported by a grant from the Center for Plant Molecular Genetics and Breeding Research, Korea Science and Engineering
Foundation. We thank Y. S. Kim, of the National Instrumentation Center for Environmental Management, Seoul National University, for technical assistance in electron microscopy.

\section{LITERATURE CITED}

1. Agrios, G. N. 1997. Plant Pathology. 4th ed. Academic Press, San Diego, CA.

2. Bell, J. N., Ryder, T. B., Wingate, V. P., Bailey, J. A., and Lamb, C. J. 1986. Differential accumulation of plant defense gene transcripts in a compatible and an incompatible plant-pathogen interaction. Mol. Cell Biol. 6:1615-1623.

3. Biggs, A. R., and Britton, K. O. 1988. Presymptom histopathology of peach trees inoculated with Botryosphaeria obtusa and Botryosphaeria dothidea. Phytopathology 78:1109-1118.

4. Biggs, A. R., and Stobbs, L. W. 1986. Fine structure of the suberized cell walls in the boundary zone and necrophylactic periderm in wounded peach bark. Can. J. Bot. 64:1606-1610.

5. Burger, O. F. 1921. Variations in Colletotrichum gloeosporioides. J. Agric. Res. 20:723-736.

6. Chase, A. R. 1988. Compendium of Ornamental Foliage Plant Diseases. The American Phytopathological Society, St. Paul, MN.

7. del Campillo, E., and Bennett, A. B. 1996. Pedicel breakstrength and cellulase gene expression during tomato flower abscission. Plant Physiol. 111:813-820.

8. Esau, K. 1965. Plant Anatomy. 2nd ed. John Wiley \& Sons, New York.

9. Hong, J. K., Lee, Y. K., Jeun, Y. C., and Hwang, B. K. 2001. Histological and ultrastructural study of susceptible and age-related resistance responses of pepper leaves to Colletotrichum coccodes infection. Plant Pathol. J. 17:128-140.

10. Hong, S.-B., Sexton, R., and Tucker, M. L. 2000. Analysis of gene promoters for two tomato polygalacturonases expressed in abscission zones and the stigma. Plant Physiol. 123:869-882.

11. Kalaitzis, P., Koehler, S. M., and Tucker, M. L. 1995. Cloning of a tomato polygalacturonase expressed in abscission. Plant Mol. Biol. 28:647-656.

12. Karnovsky, M. J. 1965. A formaldehyde-glutaraldehyde fixative of high osmolarity for use in electron microscopy. J. Cell Biol. 27:137A.

13. Kim, W. G., Cho, W. D., Jee, H. J., and Hong, S. Y. 2000. Occurrence of anthracnose on Indian fig cactus caused by Glomerella cingulata and Colletotrichum gloeosporioides. Plant Pathol. J. 16:294-296.

14. Kim, Y. H., Jun, O. K., Sung, M. J., Shin, J. S., Kim, J. H., and Jeoung, M.-I. 2000. Occurrence of Colletotrichum stem rot caused by Glomerella cingulata on graft-cactus in Korea. Plant Pathol. J. 16:242-245.

15. Kolattukudy, P. E., Kim, Y.-K., Li, D., Liu, Z.-M., and Rogers, L. 2000. Early molecular communication between Colletotrichum gloeosporioides and its host. Pages 78-98 in: Colletotrichum: Biology, Pathology, and Control. J. A. Bailey and M. J. Jeger, eds. CAB International, Wallingford, UK.

16. Lashbrook, C. C., Gonzalez-Bosch, C., and Bennett, A. B. 1994. Two divergent endo-1,4-glucanase genes exhibit overlapping expression in ripening fruit and abscising flowers. Plant Cell 6:1485-1493.

17. Marks, G. C., Berbee, J. G., and Riker, A. J. 1965. Direct penetration of leaves of Populus tremuloides by Colletotrichum gloeosporioides. Phytopathology 55:408-412.

18. Mullick, D. B. 1977. The non-specific nature of defense in bark and wood during wounding, insect and pathogen attack. Recent Adv. Phytochem. 11:395-441.

19. O'Brien, T. P., and McCully, M. E. 1981. The Study of Plant Structure. Principles and Selected Methods. Termarcarphi Pty Ltd., Melbourne, Australia.

20. O'Connell, R. J., Perfect, S., Hughes, B., Carzaniga, R., Bailey, J. A., and Green, J. 2000. Dissecting the cell biology of Colletotrichum infection processes. Pages 57-77 in: Colletotrichum: Biology, Pathology, and Control. J. A. Bailey and M. J. Jeger, eds. CAB International, Wallingford, UK.

21. Prusky, D., Koblier, I., Ardi, R., Beno-Moalem, D., Yakoby, N., and Keen, N. T. 2000. Resistance mechanisms of subtropical fruits to $\mathrm{Col}$ letotrichum gloeosporioides. Pages 232-244 in: Colletotrichum: Biology, Pathology, and Control. J. A. Bailey and M. J. Jeger, eds. CAB International, Wallingford, UK.

22. Rittinger, P. A., Biggs, A. R., and Peirson, D. R. 1987. Histochemistry of lignin and suberin deposition in boundary layers formed after wounding in various plant species and organs. Can. J. Bot. 65:1886-1982.

23. Roberts, J. A., Schindler, C. B., and Tucker, G. A. 1984. Ethylenepromoted tomato flower abscission and the possible involvement of an inhibitor. Planta 160:159-163.

24. Samuel, G. 1927. On the shot-hole disease caused by Clasterosporium carpophilum and on the shot-hole effect. Ann. Bot. 41:375-404. 
25. Sexton, R. 1995. Abscission. Pages 497-525 in: Handbook of Plant and Crop Physiology. M. Pessarakli, ed. Marcel Dekker, New York.

26. Smith, D. A. 1982. Toxicity of phytoalexins. Pages 218-252 in: Phytoalexins. J. A. Bailey and J. W. Mansfield, eds. Halsted Press, John Wiley \& Sons, New York.

27. Spurr, A. R. 1969. A low viscosity epoxy resin embedding medium for electron microscopy. J. Ultrastr. Res. 26:31-43.

28. Strange, R. N. 1998. Plants under attack II. Sci. Prog. 81(Part 1):35-68.
29. Tucker, G. A., Schindler, B., and Roberts, J. A. 1984. Flower abscission in mutant tomato plants. Planta 160:164-167.

30. Wharton, P. S., and Julian, A. M. 1996. A cytological study of compatible and incompatible interactions between Sorghum bicolor and Colletotrichum sublineolum. New Phytol. 134:25-34.

31. Wharton, P. S., Julian, A. M., and O'Connell, R. J. 2001. Ultrastructure of the infection of Sorghum bicolor by Colletotrichum sublineolum. Phytopathology 91:149-158. 